\section{Omalizumab in An 8-Year-Old Boy With Diabetes Mellitus and Refractory Chronic Spontaneous Urticaria}

Jesenak $\mathrm{M}^{1}$, Ciljakova $\mathrm{M}^{1}$, Janickova $\mathrm{M}^{2}$, Banovcin $\mathrm{P}^{1}$ ${ }^{1}$ Department of Pediatrics, Jessenius Faculty of Medicine in Martin, Comenius University in Bratislava, University Teaching Hospital, Martin, Slovakia

${ }^{2}$ Department of Stomatology and Maxillofacial Surgery, Jessenius Faculty of Medicine in Martin, Comenius University in Bratislava, University Teaching Hospital, Martin, Slovakia

J Investig Allergol Clin Immunol 2019; Vol. 29(2): 144-146 doi: $10.18176 /$ jiaci.0351

Key words: Chronic spontaneous urticaria. Autoimmunity. Omalizumab. Children.

Palabras clave: Urticaria espontánea crónica. Autoinmunidad. Omalizumab. Niños.

Chronic spontaneous urticaria (CSU) is a typical disease in older age groups; however, it also affects children. A recent systematic review analyzed treatment options for CSU in children [1]. Omalizumab is a third-line option (after single and quadruple doses of nonsedating antihistamines) for the treatment of CSU in children aged over 12 years [2]. Since only a limited number of publications to date have documented clinical efficacy and safety in children with CSU aged under 12 years, well-controlled studies with a sufficient number of patients are lacking (Table) [3-6]. The positive effect of omalizumab has also been confirmed in a 6-year-old child with refractory severe solar urticaria [7]. The youngest child treated with omalizumab was a 2 -year-old boy with severe cold-induced urticaria in whom treatment with omalizumab led to complete remission of symptoms [8]. Moreover, a small number of children aged under 12 years with CSU were reported to be part of the study population in a clinical trial, although detailed data cannot be drawn from this publication [9].

We report the case of an 8-year-old boy with diabetes mellitus type 1 , and autoimmune thyroiditis, and CSU refractory to standard recommended therapy. Diabetes mellitus and autoimmune thyroiditis were diagnosed at the age of 7, and appropriate treatment was initiated (intensified insulin therapy and L-thyroxine substitution). Thyroid values before treatment with L-thyroxine were as follows: thyroid stimulating hormone, $11.228 \mathrm{mIU} / \mathrm{L}$ (normal values 0.7-4.1); serum thyroxine T4, $14.37 \mathrm{kU} / \mathrm{L}$ (normal values 7.36-17.00); serum triiodothyronine T3, $4.72 \mathrm{kU} / \mathrm{L}$ (normal values 3.9-6.7); and antithyroid peroxidase autoantibodies, $1130.0 \mathrm{kU} / \mathrm{L}$ (normal values 0.0-9.0). Other autoimmune diseases potentially associated with diabetes mellitus and autoimmune thyroiditis (celiac disease, Addison disease, hypoparathyroidism, systemic connective tissue diseases, and vitiligo) were excluded. Three months after the diagnosis of autoimmune disease, the patient developed severe CSU (Supplementary figure 1). Despite a wide range of laboratory and clinical tests, no triggering factors were detected. Treatment with desloratadine at $2.5 \mathrm{mg}$ was initiated, although no significant response was observed. The laboratory workup revealed normal serum total IgE, eosinophilic cationic protein, and tryptase, as well as nonspecific inflammatory markers. Eosinophilia was not detected. Specific IgE against a broad panel of food and inhalant allergens was negative. Specific IgE against insulin and the basophil activation test with insulins was also negative. Changes in insulin treatment did not lead to changes in CSU symptoms. A broad spectrum of autoantibodies showed completely negative results with the exception of antithyroid peroxidase antibodies. An autologous serum skin test yielded a positive result, predicting a poor response to antihistamines. Celiac disease was excluded (negative serum markers and negative histological findings from duodenal mucosa sampled during fiberoptic gastroscopy). Microbiological tests (including Helicobacter pylori infections in the gastric specimen) and parasitological tests yielded negative results.

The absence of response to desloratadine led us to increase the dose to $10 \mathrm{mg} / \mathrm{d}$, although no effect was observed. Given the persistence of clinical symptoms and the patient's poor quality of life, we added montelukast $(5 \mathrm{mg})$ and ranitidine $(100 \mathrm{mg} / \mathrm{d})$. Although these 2 drugs are no longer included in CSU treatment guidelines, we started both owing to the parents' initial refusal of cyclosporine. However, this therapy was not successful either. As there is no validated questionnaire evaluating CSU activity for this age group, we decided to monitor disease course based on a weekly Urticaria Activity Score (UAS7), which can be used in patients aged over 12 years. The patient's score was consistently between 34 and 36 points. Since the presence of diabetes mellitus prevented us from prescribing corticosteroids, we decided to initiate treatment with a low dose of cyclosporine ( $3 \mathrm{mg} / \mathrm{kg} / \mathrm{day})$, which induced only a partial response. Given the ongoing severe CSU symptoms, poor quality of life, and difficulties in controlling diabetes, we decided to use omalizumab. After obtaining consent from both parents, we started omalizumab at a standard recommended dose of $300 \mathrm{mg}$ every 4 weeks. The dose was based on most case reports of CSU treated with omalizumab in this age category (6-12 years of age). Within 2 weeks, complete remission was achieved, with a residual serpiginous rash (Supplementary figure 2) on the trunk, which disappeared completely after the second dose. The UAS7 fell to 0 points for the next 5 months. The patient experienced a relapse of CSU within 6 weeks of completing the 12-month course. This led to repeated courses of omalizumab (a further 18 months of treatment), with rapid and complete remission of CSU within 2-4 weeks after reinitiation of the treatment every time. Achieving control of CSU made it possible to achieve control of diabetes mellitus. Glycemia before treatment with omalizumab was within the range of 9.1-20.1 $\mathrm{mml} / \mathrm{L}$ (normal values, 3.3-5.6) and glycated hemoglobin was $7.5 \%$ (normal values, $2.8-4.8 \%$ ). Once the CSU symptoms had stabilized, glycemia stabilized to the range of 5.3-12.8 $\mathrm{mmol} / \mathrm{L}$ and glycated hemoglobin dropped to $6.5 \%$. It has 
Table. Summary of Children Younger Than 12 Years With Chronic Spontaneous Urticaria or Solar Urticaria Treated With Omalizumab

\begin{tabular}{|c|c|c|c|c|c|c|c|c|c|c|c|}
\hline No. & $\begin{array}{l}\text { Age } \\
, y\end{array}$ & Sex & Diagnosis & $\begin{array}{l}\text { Comorbi- } \\
\text { dities }\end{array}$ & $\begin{array}{l}\text { Total } \\
\text { IgE, } \\
\text { IU } / \mathrm{mL}\end{array}$ & $\begin{array}{l}\text { UAS } \\
\text { Score }\end{array}$ & $\begin{array}{l}\text { Previous } \\
\text { Treatment }\end{array}$ & $\begin{array}{c}\text { Omalizumab } \\
\text { Dose }\end{array}$ & $\begin{array}{l}\text { Duration } \\
\text { of } \\
\text { Treatment }\end{array}$ & $\begin{array}{l}\text { Response } \\
\text { to } \\
\text { Treatment }\end{array}$ & Ref. \\
\hline 1 & 8 & M & $\mathrm{CSU}$ & - & 270 & Positive & $\begin{array}{l}\text { Antihistamine } \\
\text { (single dose) } \\
\text { Cyclosporine }\end{array}$ & $\begin{array}{c}300 \mathrm{mg} \\
\text { every } 4 \mathrm{wk}\end{array}$ & $11 \mathrm{mo}$ & Partial & {$[5]$} \\
\hline 2 & 11 & M & $\begin{array}{l}\text { CSU } \\
+ \\
\mathrm{AE}\end{array}$ & $\begin{array}{l}\text { Allergic } \\
\text { rhinitis }\end{array}$ & ND & Positive & $\begin{array}{c}\text { Antihistamine } \\
\text { (double combination) } \\
\text { Montelukast } \\
\text { Prednisone } \\
\text { Cyclosporine }\end{array}$ & $\begin{array}{c}300 \mathrm{mg} \\
\text { every } 4 \mathrm{wk}\end{array}$ & $6 \mathrm{mo}$ & Complete & {$[2]$} \\
\hline 3 & 8 & $\mathrm{~F}$ & CSU & - & 3281 & Positive & $\begin{array}{l}\text { Antihistamine } \\
\text { (dosage increased } \\
\text { two times) } \\
\text { Montelukast } \\
\text { Cyclosporine }\end{array}$ & $\begin{array}{l}300 \mathrm{mg} \\
\text { every } 2 \mathrm{wk} \\
(6 \mathrm{months}) \\
\rightarrow 300 \mathrm{mg} \\
\text { every } 4 \mathrm{wk}\end{array}$ & NR & Complete & {$[4]$} \\
\hline 4 & 4 & $\mathrm{~F}$ & $\mathrm{CSU}$ & $\begin{array}{l}\text { Atopic } \\
\text { eczema }\end{array}$ & 919 & Positive & $\begin{array}{l}\text { Antihistamine } \\
\text { (dosage } \\
\text { increased twice) }\end{array}$ & $\begin{array}{c}150 \mathrm{mg} \\
\text { every } 4 \mathrm{wk}\end{array}$ & NR & Complete & [3] \\
\hline 5 & 5 & $\mathrm{~F}$ & $\begin{array}{l}\text { CSU } \\
+ \\
\mathrm{AE}\end{array}$ & - & 65 & Positive & $\begin{array}{l}\text { Antihistamine } \\
\text { (dosage } \\
\text { increased twice) } \\
\text { Montelukast } \\
\text { Corticosteroids }\end{array}$ & $\begin{array}{c}150 \mathrm{mg} \\
\text { every } 4 \mathrm{wk}\end{array}$ & NR & Complete & [3] \\
\hline 6 & 10 & $\mathrm{~F}$ & $\mathrm{CSU}$ & - & 41 & Positive & $\begin{array}{l}\text { Antihistamine } \\
\text { Corticosteroids }\end{array}$ & $\begin{array}{l}300 \mathrm{mg} \\
\text { every } 4 \mathrm{wk} \\
(4 \mathrm{months}) \\
\rightarrow 300 \mathrm{mg} \\
\text { every } 2 \mathrm{wk}\end{array}$ & NR & Partial & {$[3]$} \\
\hline 7 & 6 & M & $\begin{array}{c}\text { Solar } \\
\text { urticaria }\end{array}$ & $\begin{array}{l}\text { Atopic } \\
\text { eczema }\end{array}$ & 2004 & Positive & $\begin{array}{c}\text { Antihistamine } \\
\text { (dosage increased } \\
4 \text { times) } \\
\text { Antihistamine } \\
\text { (triple combination) } \\
\text { Montelukast }\end{array}$ & $\begin{array}{c}75 \mathrm{mg} \\
\text { every } 2 \mathrm{wk} \\
\rightarrow 150 \mathrm{mg} \\
\text { every } 2 \mathrm{wk} \\
\rightarrow 225 \mathrm{mg} \\
\text { every } 2 \mathrm{wk} \\
\rightarrow 300 \mathrm{mg} \\
\text { every } 2 \mathrm{wk}\end{array}$ & $14.5 \mathrm{mo}$ & Complete & [6] \\
\hline 8 & 2 & M & $\begin{array}{l}\text { Severe } \\
\text { cold } \\
\text { urticaria }\end{array}$ & - & 14.9 & ND & $\begin{array}{c}\text { Antihistamine } \\
\text { (dosage increased twice) } \\
\text { Antihistamine } \\
\text { (double combination) } \\
\text { Montelukast }\end{array}$ & $\begin{array}{l}75 \mathrm{mg} \\
\text { every } \\
4 \mathrm{wk}\end{array}$ & $9 \mathrm{mo}$ & Complete & [8] \\
\hline
\end{tabular}

Abbreviations: AE, adverse event; CSU, chronic spontaneous urticaria; ND, not determined; NR, not reported; UAS, Urticaria Activity Score.

now been over 16 months since the last omalizumab injection, and the patient remains free of CSU symptoms.

CSU is a common comorbidity of various autoimmune diseases, including diabetes mellitus and autoimmune thyroiditis. We confirm rapid and complete remission of CSU in a child aged under 12 years with multiple autoimmune complications before initiation of omalizumab. Treatment was effective, and no adverse effects were observed. There is an urgent need for well-designed, controlled studies of CSU in patients aged under 12 years. The excellent safety profile of omalizumab confirmed in cases of asthmatic children [10] could also predict its safety in children with
CSU. Moreover, the rapid onset of action and the positive clinical response in most treated patients would support the use of omalizumab before other drugs (eg, cyclosporine or systemic corticosteroids) with potentially worse safety profiles and tolerability. Application once every 4 weeks would be another advantage.

\section{Funding}

This study was supported by the project Center of Experimental and Clinical Respirology (II. ITMS ITMS 26220120034), with cofunding from the EU. 


\section{Conflicts of Interest}

The authors declare that they have no conflicts of interest.

\section{References}

1. Ben-Shoshan M, Grattan CE. Management of pediatric urticaria with review of the literature on chronic spontaneous urticaria in children. J Allergy Clin Immunol Pract. 2018;6:1152-61.

2. Zuberbier $T$, Aberer $W$, Asero R, Abdul Latiff AH, Baker $D$, Ballmer-Weber B, et al. The EAACI/GA2LEN/EDF/WAO guideline for the definition, classification and management of urticaria. Allergy. 2018;73:1393-414.

3. Asero R, Casalone R, lemoli E. Extraordinary response to omalizumab in a child with severe chronic urticaria. Eur Ann Allergy Clin Immunol. 2014;46:41-2.

4. Netchiporouk $\mathrm{E}$, Nguyen $\mathrm{CH}$, Thuraisingham $\mathrm{T}$, Jafarian $\mathrm{F}_{\text {, }}$ Maurer M, Ben-Shoshan M. Management of pediatric chronic spontaneous and physical urticarial patients with omalizumab: case series. Pediatr Allergy Immunol. 2015;26:585-8.

5. Ossorio-Garcia D, Jimenez-Gallo D, Albarran-Planelles C, Arjona-Aguilera, Linares-Barrios M. Chronic spontaneous urticaria in an 8-year-old girl treated with omalizumab. Clin Exp Dermatol. 2016:41:919-39.

6. Viswanathan RK, Moss MH, Mathur SK. Retrospective analysis of the efficacy of omalizumab on chronic refractory urticaria. Allergy Asthma Proc. 2013;34:446-52.

7. Levi A, Tal Y, Dranitzki Z, Shalit M, Enk CD. Successful omalizumab treatment of severe solar urticaria in a 6-year-old child. Pediatr Allergy Immunol. 2015;26:588-90.

8. Alba Martin JC, Martorell Aragones A, Satorre Viejo I, Gastaldo Simeon E. Treatment of severe cold-induced urticaria in a child with omalizumab. J Investig Allergol Clin Immunol. 2015;25:295-315.

9. Sussman G, Hebert J, Barron C, Bian J, Caron-Guay RM, Laflamme $S$, et al. Real-life experiences with omalizumab for the treatment of chronic urticaria. Ann Allergy Asthma Immunol. 2014;112:170-4.

10. Chipps BE, Lanier B, Milgrom H, Deschildre A, Hedlin G, Szefler $\mathrm{SJ}$, et al. Omalizumab in children with uncontrolled allergic asthma: review of clinical trial and real-world experience. J Allergy Clin Immunol 2017;139:1431-44

Manuscript received August 19, 2018; accepted for publication November 12, 2018.

Maria Janickova

University Teaching Hospital

Martin, Slovakia

E-mail: imunoalergocentrum@gmail.com 